\title{
Non-Vitamin K Antagonist Oral Anticoagulants: Redefining the Role of the Nurse to Improve Patient Care
}

\author{
Marlene Robinson \\ Thrombosis Clinic, Hamilton General Hospital, East Hamilton, Ontario, Canada \\ Email: robinsma@hhsc.ca
}

Received 22 October 2015; accepted 26 December 2015; published 29 December 2015

Copyright (C) 2015 by author and Scientific Research Publishing Inc.

This work is licensed under the Creative Commons Attribution International License (CC BY). http://creativecommons.org/licenses/by/4.0/

(c) (i) Open Access

\begin{abstract}
Thromboembolic disorders and their associated long-term complications place a burden on patients, healthcare systems and society. Non-vitamin $K$ antagonist (VKA) oral anticoagulants (OACs), including rivaroxaban, dabigatran, apixaban and edoxaban, are effective for the prevention of stroke in patients with non-valvular atrial fibrillation and for the treatment and secondary prevention of venous thromboembolism. The increasing uptake of the non-VKA OACs in primary care lessens the burden of care and allows for an easier transition of treatment from hospital to home. This transformation in terms of patient management has resulted in the need to empower nurses working in this field to endorse management strategies with a focus on patient education and long-term management (i.e. assessment of compliance, scheduling follow-up visits). Management of both venous thromboembolism and stroke prevention in patients with non-valvular atrial fibrillation requires a multidisciplinary team approach and, looking to the future, nurses are likely to have a key role at the heart of the thrombosis team. This review aims to provide nurses with the confidence to manage patients with thromboembolic disorders, and highlights the importance of responsible non-VKA OAC use and the impact that this can have on improving patient care and outcomes.
\end{abstract}

\section{Keywords}

Atrial Fibrillation, Non-VKA OAC, Nurse-Led Management, Stroke Prevention, Venous Thromboembolism

\section{Introduction}

Thromboembolic diseases are often life-threatening but can be prevented with effective anticoagulation treatment. 
Venous thromboembolism (VTE) — the formation of a thrombus within a vein-comprises deep vein thrombosis (DVT) and pulmonary embolism (PE) and is associated with significant morbidity and mortality [1]. Although reported mortality rates from VTE vary from $5 \%$ to $23 \%$ in retrospective studies, falling to $1 \%-2 \%$ in symptomatic patients who receive adequate anticoagulation [2], there are still an estimated 500,000 and 300,000 VTE-related deaths per year in Europe and the US, respectively [3] [4]. In Europe, this equates to more than double the combined number of deaths resulting from common cancer types such as breast and prostate cancer [3] [5]. The presence of symptoms such as leg pain, tenderness, oedema or swelling is typically associated with DVT, but the condition can only be confirmed if validated diagnostic tests, i.e. compression ultrasonography, venography, magnetic resonance venography or computed tomography, are performed [6]. PE occurs when part of a thrombus detaches from a DVT, travels to the pulmonary vasculature and occludes a pulmonary artery. However, the diagnosis of a PE can be easily missed owing to its non-specific clinical symptoms, which can include dyspnoea, cough, fever, pleuritic/substernal chest pain, haemoptysis, syncope, unilateral leg pain and signs of DVT. Therefore, further objective imaging and testing specifically designed to detect PE should be performed to either exclude or confirm PE when the clinical presentation raises the suspicion of PE [7]. VTE has a substantial negative impact on patients' quality of life; patients with symptomatic DVT have worse perceptions of their health, a lower level of physical functioning and more severe role limitations attributed to physical health compared with patients with asymptomatic DVT [8]. In a recent qualitative interview-based study, patients who had been admitted to hospital for symptomatic PE described their condition as being a "life-changing distressing event" leading to behavioural changes and post-traumatic stress disorder, i.e. hypervigilance and intrusive thoughts [9]. VTE is considered a chronic disease, and patients are at significant risk of recurrent thrombosis after an initial event, with the risk of VTE recurrence greatest in the first 3 - 4 weeks [10]. Common risk factors associated with VTE recurrence include presentation of primary DVT, advanced age, proximal DVT, cancer, residual thrombus mass, male gender, thrombophilia and shorter duration of anticoagulation [11]-[14]. Post-thrombotic syndrome (PTS) is a well-recognized chronic complication occurring in nearly one-third of patients within 5 years after DVT [15], and it is estimated to affect approximately 400,000 people in the EU each year [3]. PTS is a particularly debilitating condition that is associated with significant patient morbidity and reduced quality of life [16]; some of the clinical manifestations include pain, oedema, hyperpigmentation, eczema, varicose collateral veins and venous ulceration [17]. In general, compression therapy and leg elevation are the cornerstones in the management of patients with PTS [18].

Chronic thromboembolic pulmonary hypertension (CTEPH) is a long-term complication in patients with PE and is caused by chronic major pulmonary vascular obstruction [7]. It is associated with considerable morbidity and mortality, and prospective evidence suggests a cumulative incidence of symptomatic CTEPH of approximately $4 \%$ at 2 years [19]. Risk factors for CTEPH include previous PE, younger age, larger perfusion defect and idiopathic PE [19].

Atrial fibrillation (AF) is a common cardiac arrhythmia with a prevalence of about $1.5 \%-2.0 \%$ in the general population [20]. It affects more than 6 million people in Europe [21] and 3 million people in the US [22]. AF is a major risk factor for stroke and increases the risk by approximately fivefold [23]. AF-related stroke is often more severe than strokes caused by other aetiologies [24] [25], thus impacting on patients' quality of life. Ischaemic stroke survivors may experience significant and persistent disability that can manifest in many different ways, including paralysis of one side of the body, aphasia, cognitive defects and depression [26]. Stroke survivors often require home modifications and/or mobility equipment to assist with their everyday activities, such as wheelchairs, walkers and entrance ramps. This places a substantial burden on both patients and caregivers that should not be overlooked [27].

Consequently, there is an increasing awareness that these thromboembolic disorders and their associated long-term complications contribute substantially to the healthcare burden on patients, healthcare systems and society.

Long-term anticoagulant therapy in both VTE and AF has historically involved oral vitamin K antagonists (VKAs), which have remained the mainstay of oral anticoagulation therapy for many years. Patients with VTE have typically received anticoagulant treatment with a parenteral heparin overlapping with a VKA, before transitioning to a VKA [7] [28], whereas patients with AF have received preventative anticoagulation with warfarin or another VKA [20].

Although VKAs have proven efficacy in both indications, they lack many of the properties of an ideal anticoagulant, including a wide therapeutic window, predictable dose-response, low risk of drug-drug and food-drug 
interactions and no need for routine coagulation monitoring [29]. Non-VKA oral anticoagulants (OACs), including rivaroxaban, dabigatran, apixaban and edoxaban, fulfil most of these criteria and their development has offered many practical advantages over standard therapy, thus simplifying patient management in practice.

The increasing uptake of non-VKA OACs in primary care is transforming the management of patients and the transition from hospital to home. Non-VKA OAC therapy was associated with a significantly shorter length of hospital stay compared with warfarin in patients hospitalized for non-valvular AF, DVT or PE [30]-[33], and does not required routine international normalized ratio (INR) testing. This has reshaped the role of nurses involved in anticoagulation therapy, and has provided the opportunity for a nurse-led approach with a greater focus on patient contact, education and the ongoing assessment of adherence and compliance. Anticoagulant clinics and/or units run by nurse specialists can be adjacent to hospitals and/or within general practitioners' offices. This arrangement offers many advantages, such as better communication with the patient, reduced pressure within secondary care and decreased patient wait times.

There is an increasing need to empower primary care workers in the management of chronic conditions such as VTE and AF. Therefore, this review aims to provide nurses with the understanding, required skills and confidence to manage non-VKA OAC therapy in these patient populations, subsequently improving outcomes.

\section{Non-Vitamin K Antagonist Oral Anticoagulants: What the Nurse Needs to Know}

The regulatory approvals of apixaban, dabigatran and rivaroxaban (EU, US and several other countries worldwide) and edoxaban (EU, US and Japan) in these indications derive from the successful completion of large phase III randomized clinical trials. An overview of the non-VKA OACs and their approved dosing regimens across licensed indications in Europe is shown in Table 1.

Overall, these agents have shown the potential to improve the benefit-risk profile in patients treated for acute VTE, with efficacy profiles as good as those observed in patients treated with standard of care, and similar/superior safety profiles [34]-[39]. Data from large phase III trials investigating the efficacy and safety of the non-VKA OACs in the long-term secondary prevention of VTE showed that these agents exhibited a superior efficacy compared with placebo, without significantly increasing the risk of major bleeding [34] [40] [41].

Similarly, in phase III studies in patients with non-valvular AF, non-VKA OACs were better or equivalent to warfarin for stroke prevention, but with significant improvements in safety profile. In a meta-analysis of these trials, non-VKA OACs significantly reduced the risk of stroke or systemic embolism in patients with non-valvular AF by $19 \%$ compared with warfarin, mainly driven by a significant $51 \%$ reduction in the risk of haemorrhagic stroke [42]. Non-VKA OACs also showed significantly reduced rates of all-cause mortality and intracranial haemorrhage (the most-feared complication of anticoagulation therapy), although at the cost of an increase in the rates of gastrointestinal bleeding [42]. Encouragingly, the available real-world evidence pertaining to the use of rivaroxaban and dabigatran for stroke prevention suggests similar rates of gastrointestinal bleeding between non-VKA OAC- and warfarin-treated patients [43] [44]. Similar findings have been reported in other meta-analyses of phase III trials for stroke prevention with the non-VKA OACs [45]-[47].

All non-VKA OACs are administered orally at fixed doses once or twice daily. They have shorter half-lives than VKAs (such as warfarin) as well as a faster onset of action, with peak anticoagulant effect within a few hours after drug administration. Of particular benefit, non-VKA OACs have significantly fewer food and drug interactions than the VKAs. As opposed to the indirect mode of action of the VKAs, non-VKA OACs target single, specific molecules i.e. Factor Xa and thrombin, which are critical components of the coagulation process. This is particularly true for Factor Xa, which is a crucial site of amplification in the coagulation process; the central role of Factor Xa in thrombus formation is now well recognized, with one molecule of Factor Xa being able to catalyse the formation of approximately 1000 thrombin molecules [48]. The main characteristics of non-VKA OACs compared with those of warfarin are briefly summarized in Table 2 . The main contraindications of the non-VKA OACs are shown in Table 3.

\section{Nurse-Led Management of Long-Term Anticoagulation}

\subsection{The Nurse at the Heart of a Multidisciplinary Thrombosis Team}

The increasing number of patients diagnosed with VTE/AF, combined with the complexities and patient co-morbidities that accompany these disorders, necessitates a multidisciplinary approach to patient management. 
Table 1. Dosing and regimens of non-vitamin K antagonist oral anticoagulants across approved indications in the EU [69]-[72].

\begin{tabular}{|c|c|c|c|c|}
\hline Indication & Apixaban & Dabigatran & Edoxaban & Rivaroxaban \\
\hline \multicolumn{5}{|l|}{$\begin{array}{l}\text { VTE prevention after major } \\
\text { orthopaedic surgery* }\end{array}$} \\
\hline Hip & $2.5 \mathrm{mg}$ bid & $220 \mathrm{mg}$ od & $x$ & $10 \mathrm{mg}$ od \\
\hline Knee & $2.5 \mathrm{mg}$ bid & $220 \mathrm{mg}$ od & $x$ & $10 \mathrm{mg}$ od \\
\hline \multicolumn{5}{|l|}{ VTE treatment ${ }^{\dagger}$} \\
\hline $\begin{array}{l}\text { DVT } \\
\text { PE } \\
\text { VTE secondary prevention }\end{array}$ & $\begin{array}{l}10 \mathrm{mg} \text { bid for } 7 \text { days and } \\
5 \mathrm{mg} \text { bid thereafter }\end{array}$ & $\begin{array}{l}150 \mathrm{mg} \text { bid, } \\
\text { following treatment } \\
\text { with a parenteral } \\
\text { anticoagulant for } \\
\geq 5 \text { days }\end{array}$ & $\begin{array}{c}60 \mathrm{mg} \text { od, } \\
\text { following treatment } \\
\text { with a parenteral } \\
\text { anticoagulant for } \\
\geq 5 \text { days }\end{array}$ & $\begin{array}{l}15 \mathrm{mg} \text { bid for } 21 \text { days } \\
\text { and } 20 \mathrm{mg} \text { od } \\
\text { thereafter }\end{array}$ \\
\hline $\begin{array}{l}\text { Stroke prevention in patients } \\
\text { with } \mathrm{AF}^{\ddagger}\end{array}$ & 5 mg bid & $150 \mathrm{mg}$ bid & $60 \mathrm{mg}$ od & $20 \mathrm{mg}$ od \\
\hline Acute coronary syndrome $^{\S}$ & $x$ & $x$ & $x$ & $2.5 \mathrm{mg}$ bid \\
\hline
\end{tabular}

*No dose adjustment is necessary in rivaroxaban- or apixaban-treated patients with mild ( $\mathrm{CrCl} 50-80 \mathrm{ml} / \mathrm{min})$ or moderate $(\mathrm{CrCl} 30-49 \mathrm{ml} / \mathrm{min}) \mathrm{re}-$ nal impairment. Rivaroxaban and apixaban are to be used with caution in patients with severe renal impairment (CrCl 15 - $29 \mathrm{ml} / \mathrm{min})$ and are not recommended in patients with $\mathrm{CrCl}<15 \mathrm{ml} / \mathrm{min}$. Dabigatran should only be used with caution in patients with moderate renal impairment $(\mathrm{CrCl} 30-50 \mathrm{ml} / \mathrm{min})$. These patients should initiate their treatment within $1-4$ hours following surgery with a single capsule of dabigatran $75 \mathrm{mg}$ and continuing with two capsules (150 mg) od thereafter for a total of 10 days (knee replacement surgery) or 28 - 35 days (hip replacement surgery). Dabigatran is contraindicated in patients with $\mathrm{CrCl}<30 \mathrm{ml} / \mathrm{min}$. ${ }^{\dagger}$ Rivaroxaban-treated patients with moderate $(\mathrm{CrCl} 30-49 \mathrm{ml} / \mathrm{min})$ or severe ( $\mathrm{CrCl} 15-29 \mathrm{ml} / \mathrm{min}$, rivaroxaban is to be used with caution in these patients) renal impairment should receive a reduced dose (15 mg od) if the patient's assessed risk for bleeding outweighs the risk of recurrent DVT and PE (no dose adjustment is necessary in patients with mild renal impairment $[\mathrm{CrCl} 50-80 \mathrm{ml} / \mathrm{min}])$. No dose adjustment is necessary in apixaban-treated patients with mild $(\mathrm{CrCl} 50-80 \mathrm{ml} / \mathrm{min}) \mathrm{or} \mathrm{moderate}(\mathrm{CrCl} 30-49 \mathrm{ml} / \mathrm{min})$ renal impairment, whereas in patients with severe renal impairment (CrCl $15-29 \mathrm{ml} / \mathrm{min})$ apixaban should be used with caution. Dabigatran-treated patients with moderate renal impairment ( $\mathrm{CrCl} 30-49 \mathrm{ml} / \mathrm{min}$ ) should receive either a total daily dose of $300 \mathrm{mg}$ or $220 \mathrm{mg}$ based on bleeding risk, whereas no dose adjustment is necessary in patients with mild renal impairment. A reduced dose is also recommended or should be considered in other special patient populations. A reduced dose of edoxaban (30 mg od) is recommended in patients with one or more of the following: $\mathrm{CrCl} 15$ - $50 \mathrm{ml} / \mathrm{min}$, bodyweight $\leq 60 \mathrm{~kg}$, patients receiving certain P-glycoprotein inhibitors. ${ }^{\ddagger}$ Rivaroxaban-treated patients with moderate (CrCl 30 - $\left.49 \mathrm{ml} / \mathrm{min}\right)$ or severe $(\mathrm{CrCl} 15-29 \mathrm{ml} / \mathrm{min})$ renal impairment should receive $15 \mathrm{mg}$ od. The recommended dose of apixaban is $2.5 \mathrm{mg}$ bid in patients with severe renal impairment ( $\mathrm{CrCl} 15-29 \mathrm{ml} / \mathrm{min}$ ) or with two or more of the following: age $\geq 80$ years, bodyweight $\leq 60 \mathrm{~kg}$ or serum creatinine $\geq 1.5 \mathrm{mg} / \mathrm{dl}$. Dabigatran-treated patients with moderate renal impairment ( $\mathrm{CrCl} 30-49 \mathrm{ml} / \mathrm{min}$ ) should receive a total daily dose of $300 \mathrm{mg}$ or $220 \mathrm{mg}$ based on the benefit-risk ratio. A reduced dose of edoxaban ( $30 \mathrm{mg}$ od) is recommended in patients with one or more of the following: $\mathrm{CrCl} 15$ - $50 \mathrm{ml} / \mathrm{min}$, bodyweight $\leq 60 \mathrm{~kg}$, patients receiving certain P-glycoprotein inhibitors. ${ }^{\S}$ No dose adjustment is necessary in rivaroxaban-treated patients with mild $(\mathrm{CrCl} 50-80 \mathrm{ml} / \mathrm{min})$ or moderate $(\mathrm{CrCl} 30-49 \mathrm{ml} / \mathrm{min})$ renal impairment. Approved for patients with elevated cardiac biomarkers also receiving a daily dose of 75 - $100 \mathrm{mg}$ ASA or a daily dose of 75 - $100 \mathrm{mg}$ ASA in addition to either a daily dose of $75 \mathrm{mg}$ clopidogrel or a standard daily dose of ticlopidine. AF, atrial fibrillation; ASA, acetylsalicylic acid; bid, twice daily; CrCl, creatinine clearance; DVT, deep vein thrombosis; EU, European Union; od, once daily; PE, pulmonary embolism; VTE, venous thromboembolism.

The treatment of VTE and prevention of stroke in patients with AF is not restricted to the medical aspects (i.e. diagnosis and choice of medication), but also encompasses patient education, ongoing communication and organization of scheduled follow-up visits. Owing to constraints on their time, physicians focus predominately on the essential aspects of diagnosis and treatment, with less emphasis on non-medical aspects (e.g. patient education) [49]. Therefore, nurses are needed to not only complement the physician's role but also coordinate all aspects of care and provide a more holistic approach to patient management.

Although a nurse-led multidisciplinary AF clinic can be implemented safely [50], there has not been a prospective comparison between nurse-led care and usual physician care in patients with AF in the outpatient setting. In a randomized trial, integrated nurse-led chronic care was compared with routine clinical care in ambulatory patients with AF. The nurse-led care intervention consisted of guidelines-based software and cardiologistsupervised integrated chronic care. Nurse-led care was more efficacious compared with usual care with respect to the prevention of the composite of cardiovascular death and cardiovascular hospitalization. Patients on nurse-led care pathways were shown to be better informed about their disease status and possible ways of management. Guideline recommendations were also more comprehensively implemented in nurse-led care, possibly owing to the decision-support software, which was based on guidelines [50]. Notably, nurse-led care was also shown to be effective in challenging-to-treat patients with $\mathrm{AF}$, including elderly patients with heart failure and previous stroke [50]. 
Table 2. Important clinical characteristics of non-vitamin K antagonist oral anticoagulants compared with those of warfarin [69]-[73].

\begin{tabular}{|c|c|c|c|c|c|c|}
\hline & Warfarin & Dabigatran & Rivaroxaban & Apixaban & Edoxaban & $\begin{array}{l}\text { What does it mean } \\
\text { for my patient? }\end{array}$ \\
\hline $\begin{array}{l}\text { Mechanism } \\
\text { of action }\end{array}$ & $\begin{array}{l}\text { Indirect mode of } \\
\text { action (inhibits the } \\
\text { production of blood } \\
\text { procoagulant factors } \\
\text { (i.e. prothrombin } \\
\text { and Factors VII, IX } \\
\text { and X), as well as of } \\
\text { protein C and } \\
\text { protein S }\end{array}$ & $\begin{array}{l}\text { Direct Factor IIa } \\
\text { (thrombin) inhibitor } \\
\text { (prevents thrombin } \\
\text { from converting } \\
\text { fibrinogen into } \\
\text { fibrin) }\end{array}$ & \multicolumn{3}{|c|}{$\begin{array}{l}\text { Direct Factor Xa inhibitors (prevent Factor Xa from } \\
\text { converting prothrombin to thrombin) }\end{array}$} & Not applicable \\
\hline $\begin{array}{l}\text { Needs to be } \\
\text { taken with } \\
\text { food }\end{array}$ & $\begin{array}{l}\text { With or without } \\
\text { food }\end{array}$ & $\begin{array}{l}\text { With or without } \\
\text { food }\end{array}$ & $\begin{array}{l}\text { With or without } \\
\text { food for the } 10 \mathrm{mg} \\
\text { dose; to be taken } \\
\text { with food for the } 15 \\
\text { and } 20 \mathrm{mg} \text { doses }\end{array}$ & $\begin{array}{l}\text { With or without } \\
\text { food }\end{array}$ & $\begin{array}{l}\text { With or without } \\
\text { food }\end{array}$ & $\begin{array}{l}\text { Establishing the } \\
\text { most suitable time } \\
\text { of day for the } \\
\text { patient to take } \\
\text { their medication }\end{array}$ \\
\hline $\begin{array}{l}\text { Time to peak } \\
\text { activity }\end{array}$ & $\begin{array}{l}\text { Generally } 24 \mathrm{~h} \text { but } \\
\text { can be delayed by } \\
72-96 \mathrm{~h}\end{array}$ & $0.5-2 \mathrm{~h}$ & $2-4 h$ & $3-4 h$ & $1-2 \mathrm{~h}$ & $\begin{array}{l}\text { Non-VKA OACs } \\
\text { have quicker onset } \\
\text { of action } \\
\text { compared with } \\
\text { warfarin }\end{array}$ \\
\hline Half-life & $20-60 \mathrm{~h}$ & $12-14 h$ & $\begin{array}{l}5 \text { - } 9 \text { h (young } \\
\text { individuals); } \\
11 \text { - } 13 \text { h (elderly } \\
\text { individuals) }\end{array}$ & $\sim 12 \mathrm{~h}$ & $10-14 \mathrm{~h}$ & $\begin{array}{l}\text { Warfarin has a } \\
\text { slower offset of } \\
\text { action, meaning } \\
\text { it needs to be } \\
\text { stopped earlier } \\
\text { before surgery }\end{array}$ \\
\hline $\begin{array}{l}\text { GI } \\
\text { tolerability* }\end{array}$ & No problem & Dyspepsia & No problem & No problem & No problem & $\begin{array}{l}\text { Dabigatran is not } \\
\text { appropriate for } \\
\text { patients suffering } \\
\text { from dyspepsia }\end{array}$ \\
\hline $\begin{array}{l}\text { Drug } \\
\text { interactions } \\
\text { (important } \\
\text { examples) }\end{array}$ & Numerous drugs & $\begin{array}{l}\text { Contraindicated in } \\
\text { patients receiving } \\
\text { systemic } \\
\text { ketoconazole, } \\
\text { ciclosporin, } \\
\text { itraconazole and } \\
\text { dronedarone; } \\
\text { caution needed } \\
\text { with amiodarone, } \\
\text { posaconazole, } \\
\text { quinidine, verapamil, } \\
\text { ticagrelor; should be } \\
\text { avoided in patients } \\
\text { receiving rifampicin, } \\
\text { St John's wort, } \\
\text { carbamazepine } \\
\text { or phenytoin; } \\
\text { contraindicated in } \\
\text { patients receiving } \\
\text { concomitant } \\
\text { anticoagulants }\end{array}$ & $\begin{array}{l}\text { Not recommended } \\
\text { in patients receiving } \\
\text { azole-antimycotics } \\
\text { (such as } \\
\text { ketoconazole, } \\
\text { itraconazole, } \\
\text { voriconazole, } \\
\text { posaconazole) or } \\
\text { HIV protease } \\
\text { inhibitors (e.g. } \\
\text { ritonavir); care } \\
\text { to be taken with } \\
\text { concomitant use } \\
\text { of NSAIDs, ASA } \\
\text { and PAIs; } \\
\text { contraindicated } \\
\text { in patients receiving } \\
\text { concomitant } \\
\text { anticoagulants }\end{array}$ & $\begin{array}{l}\text { Contraindicated (DVT/PE } \\
\text { indication)/caution needed } \\
\text { (prevention of VTE in } \\
\text { patients undergoing } \\
\text { elective hip or knee } \\
\text { replacement surgery/stroke } \\
\text { prevention in AF/VTE } \\
\text { secondary prevention } \\
\text { indications) in patients } \\
\text { receiving rifampicin, } \\
\text { phenytoin, carbamazepine, } \\
\text { phenobarbital, St John's } \\
\text { wort; not recommended } \\
\text { in patients receiving } \\
\text { ketoconazole, itraconazole, } \\
\text { voriconazole, posaconazole } \\
\text { and HIV protease } \\
\text { inhibitors (e.g. ritonavir); } \\
\text { contraindicated in patients } \\
\text { receiving concomitant } \\
\text { anticoagulants }\end{array}$ & $\begin{array}{l}\text { Should be used } \\
\text { with caution in } \\
\text { patients receiving } \\
\text { rifampicin; dose } \\
\text { reduction in } \\
\text { patients receiving } \\
\text { ciclosporin, } \\
\text { dronedarone, } \\
\text { erythromycin, } \\
\text { ketoconazole; } \\
\text { close scrutiny for } \\
\text { bleeding } \\
\text { in patients who } \\
\text { require chronic } \\
\text { treatment with } \\
\text { low-dose ASA } \\
\text { and/or NSAIDs; } \\
\text { contraindicated in } \\
\text { patients receiving } \\
\text { concomitant } \\
\text { anticoagulants }\end{array}$ & $\begin{array}{l}\text { Close surveillance } \\
\text { of patients } \\
\text { receiving } \\
\text { co-medications }\end{array}$ \\
\hline $\begin{array}{l}\text { Renal } \\
\text { excretion }\end{array}$ & Negligible & $85 \%$ & $\begin{array}{l}\sim 33 \% \text { as active } \\
\text { metabolite }\end{array}$ & $\sim 27 \%$ & $\sim 50 \%$ & $\begin{array}{l}\text { Close surveillance } \\
\text { of renal function } \\
\text { and evaluation of } \\
\text { drug choice/dose } \\
\text { in patients with } \\
\text { renal impairment }\end{array}$ \\
\hline
\end{tabular}

"Relating to issues other than bleeding. AF, atrial fibrillation; ASA, acetylsalicylic acid; DVT, deep vein thrombosis; GI, gastrointestinal; NSAID; non-steroidal anti-inflammatory drug; OAC, oral anticoagulant; PAI, platelet aggregation inhibitor; PE, pulmonary embolism; VKA, vitamin K antagonist, VTE, venous thromboembolism. 
Table 3. The main contraindications of the non-vitamin K antagonist oral anticoagulants.

\begin{tabular}{|c|}
\hline Non-VKA OACs should not be used in patients who \\
\hline Have active clinically significant bleeding \\
\hline Have $\mathrm{CrCl}<15 \mathrm{ml} / \mathrm{min}^{*}$ \\
\hline Are receiving concomitant treatment with any other anticoagulant \\
\hline Have hepatic disease associated with coagulopathy and/or clinically relevant bleeding risk ${ }^{\dagger}$ \\
\hline Are $<18$ years of age \\
\hline Are pregnant or breastfeeding \\
\hline Have prosthetic heart valves \\
\hline Have haemodynamically unstable pulmonary embolism or require thrombolysis or pulmonary embolectomy \\
\hline $\begin{array}{l}\text { Guidance provided by the European Medicines Agency-approved Summary of Product Characteristics regarding the main } \\
\text { contraindications of the non-VKA OACs for stroke prevention in patients with atrial fibrillation and for treatment and } \\
\text { secondary prevention of venous thromboembolism [69]-[72]. }{ }^{*} \text { Dabigatran is contraindicated in patients with } \mathrm{CrCl}<30 \mathrm{ml} / \mathrm{min} \text {. } \\
\text { Rivaroxaban and edoxaban are not recommended in patients with } \mathrm{CrCl}<15 \mathrm{ml} / \mathrm{min} \text {. }{ }^{\dagger} \text { Dabigatran is contraindicated in pa- } \\
\text { tients with hepatic impairment or liver disease that is expected to have any impact on survival. See individual Summary of } \\
\text { Product Characteristics for further details. CrCl, creatinine clearance; OAC, oral anticoagulant; VKA, vitamin K } \\
\text { antagonist. }\end{array}$ \\
\hline
\end{tabular}

Patient education, improved adherence to guideline recommendations, time spent with patients, and teamwork between the nurse and the cardiologist were put forward as the essential elements behind the benefits of the nurse-led approach [50]. Within the context of a multidisciplinary team approach, the nurse specialist acts as the "centre" of a wheel of experts coordinating and driving the communication network between the patient, haematologist, cardiologist, pharmacist and general practitioner. A key responsibility assigned to the nurse in this scenario is direct communication with the supervising physician, outlining a detailed and accurate description of the patient's current status. This can include the patient's history, the indication for treatment, type of anticoagulant, dose and regimen, and co-medications. Nurses are also tasked with identifying the need for a switch to an alternative anticoagulant (i.e. decreased time within the therapeutic range, poor venous access, anticoagulation intolerability, patient request, compliance issues, laboratory test results, e.g. creatinine clearance $[\mathrm{CrCl}]$ levels). Nurses also carry out administrative duties (i.e. patient reminders for appointments, prescription refills, scheduling of routine laboratory testing, complete blood counts).

\subsection{Important Practical Considerations}

Patients with thromboembolic diseases commonly have additional medical conditions that may complicate their management. Challenging-to-treat patient groups often encountered in primary care include patients with renal impairment, diabetes, prior stroke/transient ischaemic attack or heart failure, and elderly patients. Anticoagulant therapy with VKAs can be challenging in such patients owing to numerous drug-drug interactions [29]. Nurses should be aware that the non-VKA OACs have fewer interactions with commonly used medications and that they have shown similar efficacy to warfarin with a consistent safety profile across a wide range of difficult-tomanage patient populations [51]-[55]. Nevertheless, nurses need to be aware of the most common patient groups that require closer follow-up and/or dose reductions with non-VKA OACs.

Patients likely to benefit from the non-VKA OACs include those poorly controlled on VKAs (i.e. those with a time in therapeutic range $<70 \%$ ) [20], patients requiring medications that interact with VKAs, those without severe renal impairment or those with a prior ischaemic stroke while on a VKA with an adequate INR. In keeping with a holistic approach to patient management, these agents may provide the physician with an alternative option to warfarin, and their use can be tailored to meet the individual needs of the patient. For instance, these agents would be a good choice for patients who have geographical/economic limitations (e.g. those who live a considerable distance from centres responsible for INR testing), lifestyle limitations that prohibit regular office or clinic visits (e.g. pilots, truck drivers, business people who travel), or even physiological limitations (e.g. poor venous access, prior stroke with dysphagia). However, some patients may prefer having their anticoagulation 
levels monitored regularly, including patients who are familiar and comfortable with VKA therapy or who have no prior history of bleeding/thromboembolic events while taking VKAs, and those in whom VKA therapy is well controlled. VKA therapy may be the preferred treatment in these cases. For patients on non-VKA OACs in whom adherence is poor despite regular education, switching to a VKA with a longer half-life could be a more suitable approach [56]. A practical consideration when deciding which anticoagulant to use in patients who are unable to swallow whole tablets (e.g. those suffering from dysphagia due to a prior stroke, patients with a gastrostomy tube or those with oesophageal stricture) would be whether the anticoagulant can be administered as a crushed tablet.

Convenience, costs, risk factors for bleeding and concerns about reversibility are some of the reasons why patients may wish to switch OAC agents. Switching between OACs is mainly based on the pharmacodynamic/ pharmacokinetic properties of these agents and recommendations derived from the results of the clinical trial programmes of each drug. Nurses should take a holistic view when considering whether a patient should be switched from a VKA to a non-VKA OAC or vice versa, ensuring that the patient is made aware of the reasons why a switch may be beneficial so that they can make an informed decision. Table 4 provides guidance for switching between anticoagulants.

\subsection{The Importance of Patient Follow-Up}

The need for appropriate follow-up of patients receiving non-VKA OACs to ensure safe and effective anticoagulation treatment remains, despite the lack of a need for routine coagulation monitoring. For the treatment of VTE, a follow-up appointment or call would also help to ensure that the patient transitions smoothly from the acute to the longer-term phase of treatment, i.e. after the first 21 days of rivaroxaban or the first 7 days of apixaban treatment (Table 1), or from parenteral drug to oral dabigatran or edoxaban. Non-VKA OAC treatment of patients with thromboembolic diseases requires regular contact. Ideally, patients should have a follow-up visit every 3 months, and nurses can play a pivotal role in this regard [56]. Follow-ups provide opportunities for a nurse to carry out patient education as well as review critical aspects of patient management such as checking for adherence/compliance, signs of thromboembolic/bleeding events, side-effects (and other non-drug-related adverse events) and co-medications, and performing blood sampling for haemoglobin and renal function ( $\mathrm{CrCl}$ ), as well as assessing current weight and vital signs. In addition to the general "review list", follow-ups provide the opportunity for the nurse and patient to develop a trusting relationship. When such a relationship develops, the patient is likely to benefit from the feeling that they have somebody to talk to who cares about their wellbeing. In turn, the patient is then more likely to be honest with the nurse about any issues with treatment, for example if they have missed a dose.

Nurses should always advise patients to bring their remaining medication to appointments, which will allow for an estimation of patient adherence. The assessment of compliance/adherence can be made by asking the patient specific questions about missed doses (or by inspecting the prescribed medication in blister packs), while making sure that the patient has not been switched to another anticoagulant by another healthcare provider. To further evaluate the understanding of the need for habitual taking of the medication as prescribed, the nurse could ask the patient, "If you missed a tablet, what did you do?" and "When did you take your next tablet?". A more in-depth assessment of how a patient takes their medication can identify where compliance/adherence issues are arising. The nurse can then have a constructive discussion with the patient and provide suggestions as to how these issues could be prevented in the future (e.g. by changing the time of day the medication is taken, by making it part of the patient's daily routine, by the patient carrying the medication with them if they are often out of the house). This provides the patient with the knowledge that they need in order to take responsibility and ownership of their disease state. For patients in whom poor adherence is suspected, technological aids may help, for example smartphone applications that remind the patient about the next drug intake. Nurses also need to ensure that the patient is aware of the over-the-counter medications associated with an increased risk of bleeding (i.e. non-steroidal anti-inflammatory drugs, acetylsalicylic acid) and highlight which medications are contraindicated and which should be used with caution. Thromboembolic and bleeding complications constitute crucial elements of the nurse's checklist during follow-up and, if confirmed, these patients should be seen by a cardiologist and/or haematologist as soon as possible. In addition, caution should be taken to reduce the risk of falling, and the need for medications associated with an increased risk of falls (e.g. psychotropics, antidepressants and antipsychotics) should be reassessed [57]. Depending on the benefit-risk assessment, preventive measures 
Table 4. Guidance for switching between non-vitamin K antagonist oral anticoagulants and other anticoagulants, based on the Summaries of Product Characteristics as approved by the European Medicines Agency [69]-[72].

\begin{tabular}{|c|c|c|c|c|}
\hline & Apixaban & Dabigatran & Edoxaban & Rivaroxaban \\
\hline $\begin{array}{l}\text { Switching from } \\
\text { a VKA to a } \\
\text { non-VKA } \\
\text { OAC }\end{array}$ & $\begin{array}{l}\text { Discontinue the VKA and } \\
\text { start apixaban at INR }<2.0\end{array}$ & $\begin{array}{l}\text { Discontinue the VKA and } \\
\text { start dabigatran at INR }<2.0\end{array}$ & $\begin{array}{l}\text { Discontinue the VKA and start edoxaban at } \\
\text { INR } \leq 2.5\end{array}$ & $\begin{array}{l}\text { Discontinue the VKA and } \\
\text { start rivaroxaban at } \\
\text { INR } \leq 3.0 \text { for stroke } \\
\text { prevention in patients with } \\
\text { non-valvular AF and } \leq 2.5 \\
\text { for treatment and secondary } \\
\text { prevention of VTE }\end{array}$ \\
\hline
\end{tabular}

Switching to a Continue apixaban for at If $\mathrm{CrCl}$ is $\geq 50 \mathrm{ml} / \mathrm{min}$, VKA from a least 2 days after beginning start VKA 3 days before VKA therapy. After 2 days OAC of co-administration, obtain an INR prior to the next scheduled dose of apixaban, and continue co-administration until the INR is $\geq 2.0$
Switching from Switch at the next scheduled a parenteral anticoagulant to a non-VKA OAC discontinuing dabigatran

If $\mathrm{CrCl}$ is $30-49 \mathrm{ml} / \mathrm{min}$, start VKA 2 days before discontinuing dabigatran
Ensure continuous adequate anticoagulation during any transition to an alternate anticoagulant

Oral option: For patients currently on a $60 \mathrm{mg}$ od or $30 \mathrm{mg}$ od dose, administer edoxaban together with VKA

Patients should not take a loading dose of VKA in order to promptly achieve a stable INR between 2.0 and 3.0. It is recommended to take into account the maintenance dose of VKA and if the patient was previously taking a VKA or to use a valid INR-driven VKA treatment algorithm, in accordance with local practice

Once an INR $\geq 2.0$ is achieved, edoxaban should be discontinued. Most patients (85\%) should be able to achieve an INR $\geq 2.0$ within 14 days of concomitant administration. After 14 days it is recommended that edoxaban is discontinued and the VKA continued to achieve an INR between 2.0 and 3.0

It is recommended that during the first 14 days of concomitant therapy the INR is measured at least three times just prior to taking the daily dose of edoxaban. Concomitant edoxaban and VKA can increase the INR post edoxaban dose by up to $46 \%$

Parenteral option: Discontinue edoxaban and administe a parenteral anticoagulant and VKA at the time of the next scheduled edoxaban dose. Once a stable INR of $\geq 2.0$ is achieved, the parenteral anticoagulant should be discontinued and the VKA continued

s.c. anticoagulant (e.g. LMWH, fondaparinux): discontinue s.c. anticoagulant and start edoxaban at the time of the next scheduled s.c. dose

Intravenous UFH: discontinue the infusion and start edoxaban $4 \mathrm{~h}$ later would be due, or at the time of discontinuation in case of continuous treatment (e.g. intravenous UFH)
Give the VKA and rivaroxaban concurrently until the INR is $\geq 2.0$; standard initial VKA dosing should be given for the first 2 days of the conversion period, followed by INR-guided VKA dosing; INR should not be tested earlier than $24 \mathrm{~h}$ after the previous rivaroxaban dose
Stop the parenteral agent and start rivaroxaban 0 - $2 \mathrm{~h}$ before the time of the next scheduled administration of the parenteral agent (e.g. for $\mathrm{LMWH}$ ) would be due, or at the time of discontinuation of a continuously administered parenteral medicinal product (e.g. UFH)

Give the first dose of parenteral anticoagulant at the time the next rivaroxaban dose would be taken a parenteral

anticoagulant

from a

non-VKA

OAC
Switch at the next scheduled dose. These agents should simultaneously
Wait $12 \mathrm{~h}$ after the last dose before switching from dabigatran to a parenteral anticoagulant (non-valvular

$\mathrm{AF}$, treatment and secondary prevention of DVT/PE); wait $24 \mathrm{~h}$ after the last dose before switching from dabigatran to a parenteral anticoagulant for VTE prevention after major orthopaedic surgery
Discontinue edoxaban and start the parenteral anticoagulant at the time of the next scheduled dose
Switching

between

non-VKA

OACs [56]
Discontinue the current non-VKA OAC and begin the other non-VKA OAC at the next scheduled dose (except in situations in which higher-than-therapeutic plasma concentrations are expected, e.g. in a patient with impaired renal function)

AF, atrial fibrillation; $\mathrm{CrCl}$, creatinine clearance; DVT, deep vein thrombosis; INR, international normalized ratio; LMWH, low molecular weight heparin; OAC, oral anticoagulant; od, once daily; PE, pulmonary embolism; s.c., subcutaneous; UFH, unfractionated heparin; VKA, vitamin K antagonist; VTE, venous thromboembolism. 
(e.g. proton pump inhibitors) or drug-dose adjustments might be needed to reduce the risk of bleeding, especially when considering ongoing anticoagulation [56].

Patients receiving a non-VKA OAC need to understand why regular kidney function monitoring is important. All of the non-VKA OACs are eliminated by the kidneys to some extent, unlike the VKAs, and periodic checks of $\mathrm{CrCl}$ levels are advised. It is of critical importance for patients to understand that they can continue their treatment safely providing their kidneys are functional and able to eliminate the drug. Patients receiving a non-VKA OAC and with $\mathrm{CrCl} \geq 60 \mathrm{ml} / \mathrm{min}$ are recommended to have their renal function monitored on a yearly basis, whereas patients with $\mathrm{CrCl} 30-60 \mathrm{ml} / \mathrm{min}$ or $\mathrm{CrCl} \leq 30 \mathrm{ml} / \mathrm{min}$ should be monitored every 6 and 3 months, respectively [56]. The use of serum creatinine or estimated glomerular filtration rate (eGFR) values alone may result in a misrepresentation of renal function. This is of particular relevance in elderly patients with low bodyweight [58]. It should be noted that the use of the eGFR is not interchangeable with the value obtained using the Cockcroft-Gault equation. Any patients with reduced renal function considered for non-VKA OAC treatment should have their $\mathrm{CrCl}$ accurately calculated using the equation - this was the method used in the pivotal phase III clinical trials and is recommended in the product labels. An example is outlined below for male and female gender:

$$
\mathrm{CrCl}(\mathrm{ml} / \mathrm{min})=\frac{(140-\text { age [years }]) \times(\text { weight }[\mathrm{kg}]) \times(1.23[\mathrm{men}] \text { or } 1.04[\text { women }])}{\text { serum creatinine }(\mu \mathrm{mol} / \mathrm{l})}
$$

For a man aged 65 years, weighing $85 \mathrm{~kg}$ with a serum creatinine of $74 \mu \mathrm{mol} / \mathrm{l}$ :

$$
\mathrm{CrCl}=\frac{(140-65) \times 85 \times 1.23}{74}=106 \mathrm{ml} / \mathrm{min}
$$

For a woman aged 70 years, weighing $50 \mathrm{~kg}$ with a serum creatinine of $80 \mu \mathrm{mol} / \mathrm{l}$ :

$$
\mathrm{CrCl}=\frac{(140-70) \times 50 \times 1.04}{80}=45.5 \mathrm{ml} / \mathrm{min}
$$

Exclusion of thrombocytopenia or anaemia (especially in elderly patients), assessment of other adverse events (i.e. dyspepsia and/or vomiting), advice on red flags (i.e. what happens if symptoms get worse and when to go to the Emergency Room [ER]) and optimal management of hypertension are aspects of patient management that need to be reviewed on a regular basis. Nurses should also keep track of difficult-to-manage patients (e.g. patients with substance dependency or intravenous drug users) because it is very likely that they will be in need of more frequent follow-up visits. Of note, close supervision by family members or caregivers will be required for patients with cognitive or memory deficits to ensure adherence/compliance.

\subsection{Patient Education}

Continuous patient education on their condition as well as treatment options and duration is of utmost importance (see Section 3.5). Various approaches could be employed in this regard, including face-to-face educational sessions and supplying leaflets/brochures with detailed instructions on how to initiate anticoagulation therapy and what is involved from the patient's perspective. It is important that information is provided to patients at a level they can understand, in a manner that is timely and without overwhelming them. Nurses should avoid giving all the available information at once and should allow time for patients to digest and comprehend the most critical aspects of their disease and management. Patients also need to be given opportunities to ask questions such as, "Why has this happened to me?", "When will the pain in my leg/lungs go away?", "When will the clot go away?", "Will my condition affect my everyday activities?” and "Why do I have to be on an anticoagulant and for how long?” Patients will often seek answers to practical issues concerning their everyday life such as whether they can drink alcohol, exercise or fly abroad. Much of the nurse's role is also centred on educating patients to seek help when symptoms worsen or do not improve as expected. For example, ongoing shortness of breath, chest pain, coughing or vomiting blood for the newly diagnosed PE patient, or for the AF patient, ongoing shortness of breath or tachycardia that may indicate the need for further evaluation by a specialist. Further examination is also warranted in the case of ongoing pain, swelling or redness, or the appearance of new symptoms of shortness of breath or chest pain in patients with a current event of DVT. Nurses need to be confident in 
explaining to their patients how non-VKA OACs work, as well as the existing differences between them. All patients' questions, fears and anxieties must be adequately addressed; unanswered or partially answered questions can cause misunderstandings with regard to treatment plan and duration. The most commonly reported fear associated with the use of anticoagulation is bleeding; therefore, as part of the ongoing education process, bleeding risk should be considered in context.

For example, the nurse might reassure a patient with AF who is taking an anticoagulant for stroke prevention by saying, "Yes, bleeding can be a frightening experience, but regardless of which anticoagulant you are taking, we (the doctors and nurses) will treat it using standard methods until it is under control. Bleeding is generally not caused by the anticoagulant and, therefore, it is important we investigate what else might have caused the bleeding."

"Yes, it is true that VKAs have a reversal agent, but even that takes time to work. Non-VKA OACs do not remain in your body for very long, and ER physicians are able to manage your bleeding until the drug is eliminated from your body. If you are bleeding and need emergency care, it is important for the ER physician that you try to remember when your last dose was taken. This will help them to determine how much of the drug may still be circulating. There is a difference in the amount of circulating drug if you happened to take it an hour ago compared with 10 hours ago."

The number of patients experiencing a serious bleeding event is low, whereas a stroke or PE can be fatal or permanently disabling. Real-world experience indicates that major bleeding rates in rivaroxaban- and dabigatran-treated patients are generally similar to or lower than those seen in VKA-treated patients [59]-[66]. Importantly, most major bleeding events in real-world patients treated with rivaroxaban can be controlled through conventional bleeding management protocols [59]. Minor bleeding (e.g. epistaxis, haemorrhoidal bleeding) does not mean that anticoagulation should be abruptly discontinued, because minor bleeding is usually temporary and not predictive of major bleeding (i.e. fatal/critical organ bleeding) [56]. The message that non-VKA OACs do not cause bleeding on their own should be reinforced, and nurses should assess for underlying causes that may have preceded the bleeding event (e.g. dry nasal mucous membranes, uncontrolled hypertension, peptic ulcer disease, diverticulitis). Patients should be made aware that because they are taking an anticoagulant, it will take longer for bleeding to stop. Bleeding risk in patients with AF can be reduced by managing the patient's reversible risk factors for bleeding such as concomitant medications, non-steroidal anti-inflammatory drug use, co-morbidities such as hypertension and alcohol/drug misuse [67]. Data from the RIETE registry identified several risk factors (e.g. older age, cancer, immobility) that were independently associated with fatal bleeding in the first 3 months of VTE treatment (Table 5) [68]. Nurses should also encourage patients to use existing educational materials and to attend meetings of patient organizations (e.g. group education sessions) as a way of engaging patients in their care and improving outcomes.

Table 5. Factors affecting the risk of bleeding in patients with atrial fibrillation/venous thromboembolism while receiving an oral anticoagulant.

Factors affecting the risk of bleeding in patients with AF receiving an oral anticoagulant [67]

Intensity of anticoagulation

Age

History of stroke

Previous bleeding

Anaemia

Co-morbidities (e.g. hypertension, renal insufficiency, hepatic disease)

Co-medications (e.g. antiplatelets, NSAIDs)
Baseline risk factors for fatal bleeding during VTE treatment [68]

Age $>75$ years

Metastatic cancer

Immobility $\geq 4$ days

Major bleeding event within the past 30 days

Abnormal prothrombin time

Platelet count $<100 \times 10^{9} / 1$

$\mathrm{CrCl}<30 \mathrm{ml} / \mathrm{min}$

Anaemia

Lifestyle (e.g. alcohol consumption)

g; VTE, venous thromboembolism. 


\subsection{Hypothetical Patient Cases}

\subsubsection{Case 1}

Consider the following patient scenario: An 83-year-old female patient with a history of non-valvular AF who suffered a stroke resulting in left hemiparesis. She had not previously received treatment with an OAC. Her age and hypertension gave her a $\mathrm{CHADS}_{2}$ score of 4 and her echocardiogram was normal. It was decided that the patient should initiate warfarin therapy. Over a period of 6 months, she had supratherapeutic INRs (without any obvious cause) of 7.4, 7.0 and 9.3 on three separate occasions. Regular laboratory attendance for INR monitoring was difficult owing to her physical limitations. Follow-up visits showed that her time in therapeutic range was suboptimal, at approximately 30\%. Her kidney function was checked and she had a $\mathrm{CrCl}$ of $65 \mathrm{ml} / \mathrm{min}$. Clearly, warfarin was not working for this patient, so she was switched to a non-VKA OAC.

\subsubsection{Case 2}

And a second patient scenario: A 78-year-old patient with a history of non-valvular AF who was familiar and comfortable with warfarin therapy. His cardiologist wanted to switch him to a non-VKA OAC, highlighting the advantages of no INR testing. His INR was followed in the clinic and he had a time in therapeutic range of approximately $85 \%$, so was well controlled on warfarin. The patient was uncertain about switching but offered to try the new drug based on the recommendation of the cardiologist. Within a few weeks, it was found that the patient was having trouble adjusting to the new way of managing his condition. He did not have a problem with the new medication itself, but for years had had an understanding that having his INR measured regularly and knowing the range within which this value should fall kept him safe from stroke. This patient was subsequently switched back to warfarin.

\section{Conclusion}

The increasing uptake of non-VKA OACs in primary care is gradually transforming the management of patients and transitioning care from hospital to home. This provides the opportunity and vision for an integrated approach to disease management, with the nurse at the heart of a multidisciplinary thrombosis team. This forward thinking enables the nurse specialist to become actively involved in all aspects of the patient's non-VKA OAC journey. This redefined role for the nurse is key to patient care and contributes greatly to patient outcomes.

\section{Acknowledgements}

The author would like to acknowledge Sarah Atkinson, who provided editorial support with funding from Bayer HealthCare Pharmaceuticals.

\section{Disclosures}

Marlene Robinson acts as a consultant for Bayer, Pfizer and Boehringer Ingelheim.

\section{References}

[1] Bonner, L. and Johnson, J. (2014) Deep Vein Thrombosis: Diagnosis and Treatment. Nursing Standard, 28, 51-58. http://dx.doi.org/10.7748/ns2014.01.28.21.51.e8222

[2] Chapman, N.H., Brighton, T., Harris, M.F., Caplan, G.A., Braithwaite, J. and Chong, B.H. (2009) Venous Thromboembolism-Management in General Practice. Australian Family Physician, 38, 36-40.

[3] Cohen, A.T., Agnelli, G., Anderson, F.A., Arcelus, J.I., Bergqvist, D., Brecht, J.G., Greer, I.A., Heit, J.A., Hutchinson, J.L., Kakkar, A.K., Mottier, D., Oger, E., Samama, M.M., Spannagl, M. and VTE Impact Assessment Group in Europe (VITAE) (2007) Venous Thromboembolism (VTE) in Europe. The Number of VTE Events and Associated Morbidity and Mortality. Thrombosis and Haemostasis, 98, 756-764. http://dx.doi.org/10.1160/th07-03-0212

[4] Roger, V.L., Go, A.S., Lloyd-Jones, D.M., Benjamin, E.J., Berry, J.D., Borden, W.B., Bravata, D.M., Dai, S., Ford, E.S., Fox, C.S., Fullerton, H.J., Gillespie, C., Hailpern, S.M., Heit, J.A., Howard, V.J., Kissela, B.M., Kittner, S.J., Lackland, D.T., Lichtman, J.H., Lisabeth, L.D., Makuc, D.M., Marcus, G.M., Marelli, A., Matchar, D.B., Moy, C.S., Mozaffarian, D., Mussolino, M.E., Nichol, G., Paynter, N.P., Soliman, E.Z., Sorlie, P.D., Sotoodehnia, N., Turan, T.N., Virani, S.S., Wong, N.D., Woo, D. and Turner, M.B. (2012) Heart Disease and Stroke Statistics—2012 Update: A Report from the American Heart Association. Circulation, 125, e2-e220. 
[5] International Agency for Research on Cancer (2012) Globocan 2012: Estimated Cancer Incidence, Mortality and Prevalence Worldwide in 2012. http://globocan.iarc.fr/Pages/fact_sheets_cancer.aspx

[6] Blann, A.D. and Lip, G.Y.H. (2006) Venous Thromboembolism. British Medical Journal, 332, 215-219. http://dx.doi.org/10.1136/bmj.332.7535.215

[7] Konstantinides, S.V., Torbicki, A., Agnelli, G., Danchin, N., Fitzmaurice, D., Galiè, N., Gibbs, J.S., Huisman, M.V., Humbert, M., Kucher, N., Lang, I., Lankeit, M., Lekakis, J., Maack, C., Mayer, E., Meneveau, N., Perrier, A., Pruszczyk, P., Rasmussen, L.H., Schindler, T.H., Svitil, P., Vonk Noordegraaf, A., Zamorano, J.L. and Zompatori, M. (2014) 2014 ESC Guidelines on the Diagnosis and Management of Acute Pulmonary Embolism. European Heart Journal, 35, 3033-3069. http://dx.doi.org/10.1093/eurheartj/ehu283

[8] Beyth, R.J., Cohen, A.M. and Landefeld, C.S. (1995) Long-Term Outcomes of Deep-Vein Thrombosis. Archives of Internal Medicine, 155, 1031-1037. http://dx.doi.org/10.1001/archinte.1995.00430100053006

[9] Noble, S., Lewis, R., Whithers, J., Lewis, S. and Bennett, P. (2014) Long-Term Psychological Consequences of Symptomatic Pulmonary Embolism: A Qualitative Study. BMJ Open, 4, e004561. http://dx.doi.org/10.1136/bmjopen-2013-004561

[10] Limone, B.L., Hernandez, A.V., Michalak, D., Bookhart, B.K. and Coleman, C.I. (2013) Timing of Recurrent Venous Thromboembolism Early after the Index Event: A Meta-Analysis of Randomized Controlled Trials. Thrombosis Research, 132, 420-426. http://dx.doi.org/10.1016/j.thromres.2013.08.003

[11] Prandoni, P., Noventa, F., Ghirarduzzi, A., Pengo, V., Bernardi, E., Pesavento, R., Iotti, M., Tormene, D., Simioni, P. and Pagnan, A. (2007) The Risk of Recurrent Venous Thromboembolism after Discontinuing Anticoagulation in Patients with Acute Proximal Deep Vein Thrombosis or Pulmonary Embolism. A Prospective Cohort Study in 1626 Patients. Haematologica, 92, 199-205. http://dx.doi.org/10.3324/haematol.10516

[12] Hansson, P.O., Sorbo, J. and Eriksson, H. (2000) Recurrent Venous Thromboembolism after Deep Vein Thrombosis: Incidence and Risk Factors. JAMA Internal Medicine, 160, 769-774. http://dx.doi.org/10.1001/archinte.160.6.769

[13] Prandoni, P., Lensing, A.W.A., Prins, M.H., Bernardi, E., Marchiori, A., Bagatella, P., Frulla, M., Mosena, L., Tormene, D., Piccioli, A., Simioni, P. and Girolami, A. (2002) Residual Venous Thrombosis as a Predictive Factor of Recurrent Venous Thromboembolism. Annals of Internal Medicine, 137, 955-960. http://dx.doi.org/10.7326/0003-4819-137-12-200212170-00008

[14] Eichinger, S., Heinze, G., Jandeck, L.M. and Kyrle, P.A. (2010) Risk Assessment of Recurrence in Patients with Unprovoked Deep Vein Thrombosis or Pulmonary Embolism: The Vienna Prediction Model. Circulation, 121, 1630-1636. http://dx.doi.org/10.1161/CIRCULATIONAHA.109.925214

[15] Prandoni, P., Lensing, A.W.A., Cogo, A., Cuppini, S., Villalta, S., Carta, M., Cattelan, A.M., Polistena, P., Bernardi, E. and Prins, M.H. (1996) The Long-Term Clinical Course of Acute Deep Venous Thrombosis. Annals of Internal Medicine, 125, 1-7. http://dx.doi.org/10.7326/0003-4819-125-1-199607010-00001

[16] Kachroo, S., Boyd, D., Bookhart, B.K., LaMori, J., Schein, J.R., Rosenberg, D.J. and Reynolds, M.W. (2012) Quality of Life and Economic Costs Associated with Postthrombotic Syndrome. American Journal of Health-System Pharmacy, 69, 567-572. http://dx.doi.org/10.2146/ajhp110241

[17] Kahn, S.R. (2006) The Post-Thrombotic Syndrome: The Forgotten Morbidity of Deep Venous Thrombosis. Journal of Thrombosis and Thrombolysis, 21, 41-48. http://dx.doi.org/10.1007/s11239-006-5574-9

[18] Kahn, S.R. (2009) How I Treat Postthrombotic Syndrome. Blood, 114, 4624-4631. http://dx.doi.org/10.1182/blood-2009-07-199174

[19] Pengo, V., Lensing, A.W.A., Prins, M.H., Marchiori, A., Davidson, B.L., Tiozzo, F., Albanese, P., Biasiolo, A., Pegoraro, C., Iliceto, S. and Prandoni, P. (2004) Incidence of Chronic Thromboembolic Pulmonary Hypertension after Pulmonary Embolism. The New England Journal of Medicine, 350, 2257-2264. http://dx.doi.org/10.1056/NEJMoa032274

[20] Camm, A.J., Lip, G.Y.H., De Caterina, R., Savelieva, I., Atar, D., Hohnloser, S.H., Hindricks, G., Kirchhof, P., Bax, J.J., Baumgartner, H., Ceconi, C., Dean, V., Deaton, C., Fagard, R., Funck-Brentano, C., Hasdai, D., Hoes, A., Kirchhof, P., Knuuti, J., Kolh, P., McDonagh, T., Moulin, C., Popescu, B.A., Reiner, Z., Sechtem, U., Sirnes, P.A., Tendera, M., Torbicki, A., Vahanian, A., Windecker, S., Vardas, P., Al Attar, N., Alfieri, O., Angelini, A., Blomstrom-Lundqvist, C., Colonna, P., De Sutter, J., Ernst, S., Goette, A., Gorenek, B., Hatala, R., Heidbuchel, H., Heldal, M., Kristensen, S.D., Kolh, P., Le Heuzey, J.Y., Mavrakis, H., Mont, L., Filardi, P.P., Ponikowski, P., Prendergast, B., Rutten, F.H., Schotten, U., Van Gelder, I.C. and Verheugt, F.W.A. (2012) 2012 Focused Update of the ESC Guidelines for the Management of Atrial Fibrillation: An Update of the 2010 ESC Guidelines for the Management of Atrial Fibrillation. Developed with the Special Contribution of the European Heart Rhythm Association. European Heart Journal, 33, 2719-2747.

[21] Camm, A.J., Kirchhof, P., Lip, G.Y.H., Schotten, U., Savelieva, I., Ernst, S., Van Gelder, I.C., Al Attar, N., Hindricks, G., Prendergast, B., Heidbuchel, H., Alfieri, O., Angelini, A., Atar, D., Colonna, P., De Caterina, R., De Sutter, J., 
Goette, A., Gorenek, B., Heldal, M., Hohloser, S.H., Kolh, P., Le Heuzey, J.Y., Ponikowski, P., Rutten, F.H., Vahanian, A., Auricchio, A., Bax, J., Ceconi, C., Dean, V., Filippatos, G., Funck-Brentano, C., Hobbs, R., Kearney, P., McDonagh, T., Popescu, B.A., Reiner, Z., Sechtem, U., Sirnes, P.A., Tendera, M., Vardas, P.E., Widimsky, P., Vardas, P.E., Agladze, V., Aliot, E., Balabanski, T., Blomstrom-Lundqvist, C., Capucci, A., Crijns, H., Dahlof, B., Folliguet, T., Glikson, M., Goethals, M., Gulba, D.C., Ho, S.Y., Klautz, R.J., Kose, S., McMurray, J., Perrone Filardi, P., Raatikainen, P., Salvador, M.J., Schalij, M.J., Shpektor, A., Sousa, J., Stepinska, J., Uuetoa, H., Zamorano, J.L. and Zupan, I. (2010) Guidelines for the Management of Atrial Fibrillation: The Task Force for the Management of Atrial Fibrillation of the European Society of Cardiology (ESC). European Heart Journal, 31, 2369-2429. http://dx.doi.org/10.1093/eurheartj/ehq278

[22] Heeringa, J. (2010) Atrial Fibrillation: Is the Prevalence Rising? EP Europace, 12, 451-452. http://dx.doi.org/10.1093/europace/euq056

[23] Wolf, P.A., Abbott, R.D. and Kannel, W.B. (1991) Atrial Fibrillation as an Independent Risk Factor for Stroke: The Framingham Study. Stroke, 22, 983-988.

[24] Lin, H.J., Wolf, P.A., Kelly-Hayes, M., Beiser, A.S., Kase, C.S., Benjamin, E.J. and D’Agostino, R.B. (1996) Stroke Severity in Atrial Fibrillation. The Framingham Study. Stroke, 27, 1760-1764. http://dx.doi.org/10.1161/01.STR.27.10.1760

[25] Jørgensen, H.S., Nakayama, H., Reith, J., Raaschou, H.O. and Olsen, T.S. (1996) Acute Stroke with Atrial Fibrillation. The Copenhagen Stroke Study. Stroke, 27, 1765-1769. http://dx.doi.org/10.1161/01.STR.27.10.1765

[26] Kelly-Hayes, M., Beiser, A., Kase, C.S., Scaramucci, A., D'Agostino, R.B. and Wolf, P.A. (2003) The Influence of Gender and Age on Disability Following Ischemic Stroke: The Framingham Study. Journal of Stroke and Cerebrovascular Diseases, 12, 119-126. http://dx.doi.org/10.1016/S1052-3057(03)00042-9

[27] Caro, J.J., Huybrechts, K.F. and Duchesne, I. (2000) Management Patterns and Costs of Acute Ischemic Stroke: An International Study. Stroke, 31, 582-590. http://dx.doi.org/10.1161/01.str.31.3.582

[28] Kearon, C., Akl, E.A., Comerota, A.J., Prandoni, P., Bounameaux, H., Goldhaber, S.Z., Nelson, M.E., Wells, P.S., Gould, M.K., Dentali, F., Crowther, M. and Kahn, S.R. (2012) Antithrombotic Therapy for VTE Disease: Antithrombotic Therapy and Prevention of Thrombosis. 9th ed: American College of Chest Physicians Evidence-Based Clinical Practice Guidelines. Chest, 141, e419S-e494S.

[29] Ageno, W., Gallus, A.S., Wittkowsky, A., Crowther, M., Hylek, E.M. and Palareti, G. (2012) Oral Anticoagulant Therapy: Antithrombotic Therapy and Prevention of Thrombosis, 9th ed: American College of Chest Physicians Evidence-Based Clinical Practice Guidelines. Chest, 141, e44S-e88S.

[30] Laliberté, F., Pilon, D., Raut, M.K., Nelson, W.W., Olson, W.H., Germain, G., Schein, J.R. and Lefebvre, P. (2014) Hospital Length of Stay: Is Rivaroxaban Associated with Shorter Inpatient Stay Compared to Warfarin among Patients with Non-Valvular Atrial Fibrillation? Current Medical Research and Opinion, 30, 645-653. http://dx.doi.org/10.1185/03007995.2013.867843

[31] van Bellen, B., Bamber, L., Correa de Carvalho, F., Prins, M., Wang, M. and Lensing, A.W.A. (2014) Reduction in the Length of Stay with Rivaroxaban as a Single-Drug Regimen for the Treatment of Deep Vein Thrombosis and Pulmonary Embolism. Current Medical Research and Opinion, 30, 829-837. http://dx.doi.org/10.1185/03007995.2013.879439

[32] Vorchheimer, D.A., Lee, J., Muller, S., Zafar, M.U., Copeland-Halperin, R., Caliendo, G. and Meyer, J. (2013) Abstract 1237-47 Dabigatran versus Standard Antithrombotic Therapy for New Onset Nonvalvular Atrial Fibrillation: Impact on Hospital Length of Stay. Journal of the American College of Cardiology, 61, E377.

[33] Xie, L., Vo, L., Keshishian, A., Price, K., Singh, P., Mardekian, J., Bruno, A., Baser, A., Kim, J., Tan, W. and Trocio, J. (2015) Comparison of Hospital Length of Stay and Costs between Non-Valvular Atrial Fibrillation Patients Treated with Either Apixaban or Warfarin. Circulation: Cardiovascular Quality and Outcomes, 8, A234.

[34] The EINSTEIN Investigators (2010) Oral Rivaroxaban for Symptomatic Venous Thromboembolism. The New England Journal of Medicine, 363, 2499-2510. http://dx.doi.org/10.1056/NEJMoa1007903

[35] The EINSTEIN-PE Investigators (2012) Oral Rivaroxaban for the Treatment of Symptomatic Pulmonary Embolism. The New England Journal of Medicine, 366, 1287-1297. http://dx.doi.org/10.1056/NEJMoa1113572

[36] Agnelli, G., Buller, H.R., Cohen, A., Curto, M., Gallus, A.S., Johnson, M., Masiukiewicz, U., Pak, R., Thompson, J., Raskob, G.E. and Weitz, J.I. (2013) Oral Apixaban for the Treatment of Acute Venous Thromboembolism. The New England Journal of Medicine, 369, 799-808. http://dx.doi.org/10.1056/NEJMoa1302507

[37] The Hokusai-VTE Investigators (2013) Edoxaban versus Warfarin for the Treatment of Symptomatic Venous Thromboembolism. The New England Journal of Medicine, 369, 1406-1415. http://dx.doi.org/10.1056/NEJMoa1306638

[38] Schulman, S., Kearon, C., Kakkar, A.K., Mismetti, P., Schellong, S., Eriksson, H., Baanstra, D., Schnee, J. and Goldhaber, S.Z. (2009) Dabigatran versus Warfarin in the Treatment of Acute Venous Thromboembolism. The New Eng- 
land Journal of Medicine, 361, 2342-2352. http://dx.doi.org/10.1056/NEJMoa0906598

[39] Schulman, S., Kakkar, A.K., Goldhaber, S.Z., Schellong, S., Eriksson, H., Mismetti, P., Vedel Christiansen, A., Friedman, J., Le Maulf, F., Peter, N. and Kearon, C. (2014) Treatment of Acute Venous Thromboembolism with Dabigatran or Warfarin and Pooled Analysis. Circulation, 129, 764-772. http://dx.doi.org/10.1161/CIRCULATIONAHA.113.004450

[40] Agnelli, G., Buller, H.R., Cohen, A., Curto, M., Gallus, A.S., Johnson, M., Porcari, A., Raskob, G.E. and Weitz, J.I. (2013) Apixaban for Extended Treatment of Venous Thromboembolism. The New England Journal of Medicine, 368, 699-708. http://dx.doi.org/10.1056/NEJMoa1207541

[41] Schulman, S., Kearon, C., Kakkar, A.K., Schellong, S., Eriksson, H., Baanstra, D., Kvamme, A.M., Friedman, J., Mismetti, P. and Goldhaber, S.Z. (2013) Extended Use of Dabigatran, Warfarin, or Placebo in Venous Thromboembolism. The New England Journal of Medicine, 368, 709-718. http://dx.doi.org/10.1056/NEJMoa1113697

[42] Ruff, C.T., Giugliano, R.P., Braunwald, E., Hoffman, E.B., Deenadayalu, N., Ezekowitz, M.D., Camm, A.J., Weitz, J.I., Lewis, B.S., Parkhomenko, A., Yamashita, T. and Antman, E.M. (2014) Comparison of the Efficacy and Safety of New Oral Anticoagulants with Warfarin in Patients with Atrial Fibrillation: A Meta-Analysis of Randomised Trials. The Lancet, 383, 955-962. http://dx.doi.org/10.1016/S0140-6736(13)62343-0

[43] Chang, H.Y., Zhou, M., Tang, W., Alexander, G.C. and Singh, S. (2015) Risk of Gastrointestinal Bleeding Associated with Oral Anticoagulants: Population Based Retrospective Cohort Study. The British Medical Journal, 350, h1585.

[44] Abraham, N.S., Singh, S., Alexander, G.C., Heien, H., Haas, L.R., Crown, W. and Shah, N.D. (2015) Comparative Risk of Gastrointestinal Bleeding with Dabigatran, Rivaroxaban, and Warfarin: Population Based Cohort Study. The British Medical Journal, 350, h1857.

[45] Miller, C.S., Grandi, S.M., Shimony, A., Filion, K.B. and Eisenberg, M.J. (2012) Meta-Analysis of Efficacy and Safety of New Oral Anticoagulants (Dabigatran, Rivaroxaban, Apixaban) versus Warfarin in Patients with Atrial Fibrillation. American Journal of Cardiology, 110, 453-460. http://dx.doi.org/10.1016/j.amjcard.2012.03.049

[46] Lip, G.Y.H., Larsen, T.B., Skjøth, F. and Rasmussen, L.H. (2012) Indirect Comparisons of New Oral Anticoagulant Drugs for Efficacy and Safety When Used for Stroke Prevention in Atrial Fibrillation. Journal of the American College of Cardiology, 60, 738-746. http://dx.doi.org/10.1016/j.jacc.2012.03.019

[47] Chatterjee, S., Sardar, P., Biondi-Zoccai, G. and Kumbhani, D.J. (2013) New Oral Anticoagulants and the Risk of Intracranial Hemorrhage: Traditional and Bayesian Meta-Analysis and Mixed Treatment Comparison of Randomized Trials of New Oral Anticoagulants in Atrial Fibrillation. JAMA Neurology, 70, 1486-1490.

[48] Mann, K.G., Brummel, K. and Butenas, S. (2003) What Is All That Thrombin for? Journal of Thrombosis and Haemostasis, 1, 1504-1514. http://dx.doi.org/10.1046/j.1538-7836.2003.00298.x

[49] Berti, D., Hendriks, J.M., Brandes, A., Deaton, C., Crijns, H.J., Camm, A.J., Hindricks, G., Moons, P. and Heidbuchel, H. (2013) A Proposal for Interdisciplinary, Nurse-Coordinated Atrial Fibrillation Expert Programmes as a Way to Structure Daily Practice. European Heart Journal, 34, 2725-2730. http://dx.doi.org/10.1093/eurheartj/eht096

[50] Hendriks, J.M., de Wit, R., Crijns, H.J., Vrijhoef, H.J., Prins, M.H., Pisters, R., Pison, L.A., Blaauw, Y. and Tieleman, R.G. (2012) Nurse-Led Care vs. Usual Care for Patients with Atrial Fibrillation: Results of a Randomized Trial of Integrated Chronic Care vs. Routine Clinical Care in Ambulatory Patients with Atrial Fibrillation. European Heart Journal, 33, 2692-2699. http://dx.doi.org/10.1093/eurheartj/ehs071

[51] Lega, J.C., Bertoletti, L., Gremillet, C., Chapelle, C., Mismetti, P., Cucherat, M., Vital-Durand, D. and Laporte, S. (2014) Consistency of Safety and Efficacy of New Oral Anticoagulants Across Subgroups of Patients with Atrial Fibrillation. PLoS ONE, 9, e91398. http://dx.doi.org/10.1371/journal.pone.0091398

[52] Bauersachs, R.M., Lensing, A.W.A., Prins, M.H., Kubitza, D., Pap, Á.F., Decousus, H., Beyer-Westendorf, J. and Prandoni, P. (2014) Rivaroxaban versus Enoxaparin/Vitamin K Antagonist Therapy in Patients with Venous Thromboembolism and Renal Impairment. Thrombosis Journal, 12, 25. http://dx.doi.org/10.1186/1477-9560-12-25

[53] Prins, M.H., Lensing, A.W.A., Brighton, T.A., Lyons, R.M., Rehm, J., Trajanovic, M., Davidson, B.L., BeyerWestendorf, J., Pap, Á.F., Berkowitz, S.D., Cohen, A.T., Kovacs, M.J., Wells, P.S. and Prandoni, P. (2014) Oral Rivaroxaban versus Enoxaparin with Vitamin K Antagonist for the Treatment of Symptomatic Venous Thromboembolism in Patients with Cancer (EINSTEIN-DVT and EINSTEIN-PE): A Pooled Subgroup Analysis of Two Randomised Controlled Trials. The Lancet Haematology, 1, e37-e46. http://dx.doi.org/10.1016/S2352-3026(14)70018-3

[54] Schulman, S., Eriksson, H., Goldhaber, S.Z., Kakkar, A., Kearon, C., Schellong, S.M., Feuring, M., Peter, N. and Friedman, J. (2013) Abstract 582 Influence of Active Cancer on the Efficacy and Safety of Dabigatran versus Warfarin for the Treatment of Acute Venous Thromboembolism: A Pooled Analysis from RE-COVER and RE-COVER II. Blood (ASH Annual Meeting Abstracts), 122.

[55] Raskob, G.E., Buller, H., Angchaisuksiri, P., Oh, D., Boda, Z., Lyons, R.M., Weitz, J.I., Zhang, G., Lanz, H.J. and Mercuri, M. (2013) Abstract 211 Edoxaban for Long-Term Treatment of Venous Thromboembolism in Cancer Patients. 
Blood (ASH Annual Meeting Abstracts), 122.

[56] Heidbuchel, H., Verhamme, P., Alings, M., Antz, M., Hacke, W., Oldgren, J., Sinnaeve, P., Camm, A.J. and Kirchhof, P. (2013) European Heart Rhythm Association Practical Guide on the Use of New Oral Anticoagulants in Patients with Non-Valvular Atrial Fibrillation. Europace, 15, 625-651. http://dx.doi.org/10.1093/europace/eut083

[57] Hartikainen, S., Lonnroos, E. and Louhivuori, K. (2007) Medication as a Risk Factor for Falls: Critical Systematic Review. Journals of Gerontology Series A: Biological Sciences and Medical Sciences, 62, 1172-1181. http://dx.doi.org/10.1093/gerona/62.10.1172

[58] National Health Service (2014) Guidelines for Prescribing in Primary Care: Atrial Fibrillation. http://medicines.necsu.nhs.uk/wp-content/uploads/2014/10/Gateshead-Atrial-Fibrillation-in-Primary-Care-Guidelines.p df.

[59] Beyer-Westendorf, J., Förster, K., Pannach, S., Ebertz, F., Gelbricht, V., Thieme, C., Michalski, F., Kohler, C., Werth, S., Sahin, K., Tittl, L., Hänsel, U. and Weiss, N. (2014) Rates, Management, and Outcome of Rivaroxaban Bleeding in Daily Care: Results from the Dresden NOAC Registry. Blood, 124, 955-962.

[60] Tamayo, S., Frank, P.W., Patel, M., Sicignano, N., Hopf, K.P., Fields, L.E., Sarich, T., Wu, S., Yannicelli, D. and Yuan, Z. (2015) Characterizing Major Bleeding in Patients with Nonvalvular Atrial Fibrillation: A Pharmacovigilance Study of 27,467 Patients Taking Rivaroxaban. Clinical Cardiology, 38, 63-68. http://dx.doi.org/10.1002/clc.22373

[61] Tamayo, S., Patel, M., Yuan, Z., Hopf, K.P. and Peacock, F. (2015) Abstract 1236M-07 Post-Marketing Pharmacovigilance Study for the Active Detection and Evaluation of Major Bleeding in Rivaroxaban Users with Non-Valvular Atrial Fibrillation. Journal of the American College of Cardiology, 65, A281. http://dx.doi.org/10.1016/s0735-1097(15)60281-9

[62] Olesen, J.B., Lip, G.Y.H., Lindhardsen, J., Lane, D.A., Ahlehoff, O., Hansen, M.L., Raunso, J., Tolstrup, J.S., Hansen, P.R., Gislason, G.H. and Torp-Pedersen, C. (2011) Risks of Thromboembolism and Bleeding with Thromboprophylaxis in Patients with Atrial Fibrillation: A Net Clinical Benefit Analysis Using a "Real World", Nationwide Cohort Study. Thrombosis and Haemostasist, 106, 739-749. http://dx.doi.org/10.1160/TH11-05-0364

[63] Friberg, L., Rosenqvist, M. and Lip, G.Y.H. (2012) Evaluation of Risk Stratification Schemes for Ischaemic Stroke and Bleeding in 182,678 Patients with Atrial Fibrillation: The Swedish Atrial Fibrillation Cohort Study. European Heart Journal, 33, 1500-1510. http://dx.doi.org/10.1093/eurheartj/ehr488

[64] Graham, D.J., Reichman, M.E., Wernecke, M., Zhang, R., Southworth, M.R., Levenson, M., Sheu, T.C., Mott, K., Goulding, M.R., Houstoun, M., MaCurdy, T.E., Worrall, C. and Kelman, J.A. (2015) Cardiovascular, Bleeding, and Mortality Risks in Elderly Medicare Patients Treated with Dabigatran or Warfarin for Non-Valvular Atrial Fibrillation. Circulation, 131, 157-164. http://dx.doi.org/10.1161/CIRCULATIONAHA.114.012061

[65] Larsen, T.B., Rasmussen, L.H., Skjøth, F., Due, K.M., Callréus, T., Rosenzweig, M. and Lip, G.Y.H. (2013) Efficacy and Safety of Dabigatran Etexilate and Warfarin in "Real-World" Patients with Atrial Fibrillation: A Prospective Nationwide Cohort Study. Journal of the American College of Cardiology, 61, 2264-2273. http://dx.doi.org/10.1016/j.jacc.2013.03.020

[66] Larsen, T.B., Gorst-Rasmussen, A., Rasmussen, L.H., Skjoth, F., Rosenzweig, M. and Lip, G.Y.H. (2014) Bleeding Events among New Starters and Switchers to Dabigatran Compared with Warfarin in Atrial Fibrillation. American Journal of Medicine, 127, 650-656. http://dx.doi.org/10.1016/j.amjmed.2014.01.031

[67] Lip, G.Y.H., Andreotti, F., Fauchier, L., Huber, K., Hylek, E., Knight, E., Lane, D., Levi, M., Marín, F., Palareti, G. and Kirchhof, P. (2011) Bleeding Risk Assessment and Management in Atrial Fibrillation Patients. Executive Summary of a Position Document from the European Heart Rhythm Association [EHRA], Endorsed by the European Society of Cardiology [ESC] Working Group on Thrombosis. Thrombosis and Haemostasis, 106, 997-1011. http://dx.doi.org/10.1160/TH11-10-0690

[68] Nieto, J.A., Solano, R., Ruiz-Ribó, M.D., Ruiz-Gimenez, N., Prandoni, P., Kearon, C., Monreal, M. and for the RIETE Investigators (2010) Fatal Bleeding in Patients Receiving Anticoagulant Therapy for Venous Thromboembolism: Findings from the RIETE Registry. Journal of Thrombosis and Haemostasis, 8, 1216-1222. http://dx.doi.org/10.1111/j.1538-7836.2010.03852.x

[69] Bristol-Myers Squibb and Pfizer (2015) Summary of Product Characteristics. Eliquis ${ }^{\circledR}$. http://www.ema.europa.eu/docs/en_GB/document_library/EPAR_-_Product_Information/human/002148/WC5001077 28.pdf

[70] Boehringer Ingelheim International GmbH (2015) Summary of Product Characteristics. Pradaxa ${ }^{\circledR}$. http://www.ema.europa.eu/docs/en_GB/document_library/EPAR___Product_Information/human/002629/WC5001890 45.pdf

[71] Daiichi Sankyo Europe GmbH (2015) Summary of Product Characteristics. Lixiana ${ }^{\circledR}$. http://www.ema.europa.eu/docs/en_GB/document_library/EPAR_-_Product_Information/human/002629/WC5001890 $\underline{45 . p d f}$ 
[72] Bayer Pharma AG (2015) Summary of Product Characteristics. Xarelto ${ }^{\circledR}$. http://www.ema.europa.eu/docs/en_GB/document_library/EPAR_-_Product_Information/human/000944/WC5000571 08.pdf

[73] Bristol-Myers Squibb (2015) Prescribing Information Coumadin. http://packageinserts.bms.com/pi/pi coumadin.pdf 